\title{
TWELFTH INTERNATIONAL CONGRESS OF APPLIED PSYCHOLOGY
}

$\mathrm{W}$ ITTGENSTEIN once argued that no paper read to a scientific society should last more than fifteen minutes, because anyone who had anything to say on any subject could easily say it in that time. He would probably have regarded with some horror the Twelfth International Congress of Applied Psychology, which met in London during July 18-23. Few of the speakers named on the programme took less than half an hour, and there were more than a hundred of them. Yet only four special lecturers had been asked to talk for more than twenty minutes. Perhaps many of the others felt that, having come from the ends of the earth, or thereabouts, they could justify themselves-to themselves, or to the bodies which in certain cases had paid their expenses-only by going on and on. Nor was the unbargained-for time always well spent. In fact, and as usual, the people who spoke the longest had the least to say.

'Nevertheless, the Congress was a good one, and on the whole it took satisfactory account of an important point made by the president, Dr. C. B. Frisby (London), in his opening speech, when he stressed the need, in applied psychology, for paying more attention to the attitudes displayed to the investigator by the investigated. There was less discussion of his equally important contention that, in the implementation of the results of research, the psychologist must beware of the hazards of leaving all the work to others. Dr. Frisby said he does not see, in the psychological field, the possibility of an equivalent to the engineer, who can interpret the discoveries of the physicist. There is, in fact, a danger that attempts may be made by others to apply procedures found useful in situations which psychologically are very different. At the same session, the Lord President of the Council, Lord Salisbury, wisely urged that psychologists should be ready to "come down every now and then from the rarified air they normally breathe and be ready to explain, in words the general public can understand, what they are doing and why they are doing it. ... It is because the ordinary man is bewildered that he is distrustful. He feels there must be a catch in it".

Sir Frederic Bartlett (Cambridge), in a lecture on "Timing", gave an admirable exposition of the outcome of recent experimental studies of skill. Two or more related sequences of events are involved whenever a skilled performance of any kind or level occurs. One provides the performer with information; the other consists of what he does about it. One is a receptor sequence; the other is effector. In 'good' timing, each effector constituent enters the sequence at such a point that it produces the maximum of desired effect with the minimum of associated effort. Minimal effort has two empirical signs : an absence of both forced hurry and forced loitering. Experiment has shown that timing is principally controlled by adjustments of the relatively stationary intervals in effector sequences. During these intervals, central, perceptual and intellectual activity is demanded; and it is from this that timing derives its remarkable range of rapid adaptability. In human social affairs, Sir Frederic argued, timing is just as important as it is in the simpler, bodily skills.

Prof. E. Mira y Lopez (Rio de Janeiro) reported the results of experiments on the effect of foresight and attitude on mental output. His subjects had been asked to predict their own health, work, wealth, social prestige, domestic happiness and individual contentment one week, one month, one year, ten years ahead. His main early findings were that the accuracy of prediction depended more on the nature of the facts predicted, and the predictor's psychological make-up, than on the passage of time ; that pessimistic predictions about health were more often confirmed than optimistic ones; that predictions about work output were more often accurate than predictions about social prestige, wealth or domestic happiness; and that in the case of neurotic and psychotic subjects fear seemed to dominate their motivation. All this led to a further inquiry into the association between 'force of belief' and accuracy of prediction. A study of attitudes towards psychological tests produced the conclusion that "extrinsic factors, especially of a conative kind, may influence performance in a battery of aptitude tests almost as much as the factors theoretically involved in its normal execution". There is nothing new here, but the additional evidence will be useful.

At the beginning of a symposium on "The Evaluation of Methods in Applied Psychology and the Problem of Criteria", Mr. J. M. Faverge (Paris) strongly advocated the setting up of good criteria at the design stage of investigations; and in doing so he uttered a warning-never unnecessary, it seemsagainst the hazards of small samples in psychological research. Prof. J. C. Flanagan (Pittsburgh), who followed, spoke some more very good sense on both these points. He said that for the psychologist in the field there is no more fundamental question than, Are we really helping people to solve their problems? The ultimate criteria must always be of the 'on the job' variety; but intermediate criteria, too, are required. In industry, complications often arise through contamination resulting from informal discussion between people responsible for collecting predictor data and others responsible for collecting criterion data.

Prof. R. Bonnardel (Paris), in another symposium, on "The Organization and Application of Research", made a good and uncommon point in arguing that the industrial psychologist is really the only one of his kind who has much chance of studying normal people in the normal conditions in which they spend most of their waking lives. Growing co-operation between practitioners in the field and psychologists in university departments is improving our ability to make use of the opportunity. However, Prof. Bonnardel shared the view of Prof. L. S. Hearnshaw (Liverpool), expressed elsewhere, that the former are still too little inclined to classify, while the latter are apt to classify prematurely. Dr. H. E. Page (Washington), who followed, spoke from a wealth of experience in the administration of science in the U.S. Office of Naval Research. After describing how this organization works, he talked discreetly of some of its major difficulties. One arises from the very great influence exercised by a very few psychologists, through their membership of controlling cornmittees of one kind and another. He did not claim that this is necessarily a bad thing; but he maintained that it is an exceedingly important one. Another difficulty concerned the implementation of research findings. Dr. Frisby had hinted that this is intensified by the 
entry of untrained people into the psychologist's territory. Dr. Page suggested--without mentioning Dr. Erisby's comment, which he may not have heard-that perhaps the psychologist is himself to blame for this. Indeed, he seemed to extend the main point made by Lord Salisbury, for he went on to say: "More scientists should learn to omploy the language and concepts of their users. Many have no desire to do this". He added that the personality of the translator may be more important than his knowledge of information theory.

Prof. O. Klineberg (Paris), who took the chair at a symposium on "Attitudes, Opinions and Behaviour", made a useful and all-too-brief contribution of his own when he took two of his main speakers to task for suggesting that it is unnecessary for psychologists, sociologists and others in this field to agree on the use of terms. It is indeed difficult to discern just what Prof. R. Clémens (Liège) had meant when he said that psychology and sociology differ largely in emphasis. Dr. H, Durant (London) had side-stepped the issuo by dismissing it as "partly semantic". It will be interesting to discover, some day, how much of the present-day confusion in this area could be got rid of by the simple expedient of clearing our lines of communication in the way Dr. Klineberg proposed.

The Congress, which met in plenary session for major symposia each morning, and split into six parts each afternoon, for four minor symposia and two series of individual papers, was housed in the Beveridge Hall of the Senate House, University of London, in various theatres in Birkbeck College, and in the Masaryk Hall of the School of Slavonic Studies. One of the four special lectures was given by Prof. C. Pellizzi, head of the Human Relations Division of the European Productivity Agency, which had generously provided simultaneous translation facilities in the Beveridge Hall. Another, delivered at the closing session, was by Prof. M. S. Viteles (Philadelphia). Entitled "The Now Utopia", this last lecture provided the appliod psychologist with yot another warning that he must be careful how and where he walks. He may find it difficult to avoid making value-judgments of considerable importance to himself and others; but he should at least know when he is doing so. "We cannot allow the fact that our young science is making some contribution to the solution of present-day problems to encourage us to think of ourselves as the arehitects of the Now Utopia."

Among the social events was a banquet at the Hurlingham Club, with a speech by Lord Halsbury in five languages. ALFO RODGER

\section{UNIVERSITY AFFAIRS IN GREAT BRITAIN, 1953-54}

T HE "Returns from Universities and University Colleges in receipt of Treasury Grant for the Academio Year 1953-54", issued by the University Grants Committee*, shows a further decline of 872 in the number of full-time students- to 80,602, compared with 81,474 in $1952-53$ and 85,314 in $1950-51$. In the English universities there were 646 fewer fulltime men students but 184 more women than in 1952-53 ; for Wales there were 146 fewer men and

* Universities Grants Committee. Returns from Universities and University Colleges in receipt of Treasury Grant-Academic Yea
1953-54. (Cmd.9477.) Pp. 44. (London: H. M O.
44 fewer women, and for Scotland 201 fewer men and 19 fewer women. Overseas full-time students from within the British Commonwealth increased by 368 to 4,607 ; but part-time students $(1,819)$ were 23 fewer than in 1952-53. Students from foreign countries increased by 144 to 3,373 full-time, and by 77 to 1,379 part-time, students compared with 195253. There was no appreciable change in the percentage distribution of full-time students among the faculties: students of technology increased by 43 to 10,036 , but those of pure science decreased by 30 to 17,001 , the percentage distribution being 12.4 and $21 \cdot 1$, respectively, compared with 43 per cent for arts, $16 \cdot 4$ for medicine, $3 \cdot 2$ for dentistry, $2 \cdot 6$ for agriculture and 1.3 per cent for veterinary science. Although the percentage of arts students was slightly higher, the number of students $(34,673)$ was smaller by 243. Full-time advanced students of puro seience increased by 245 to 3,290 , of technology by 224 to 1,381 , of arts by 290 to 3,596 , of agriculture by 9 to 290 , and of veterinary science by 5 to 12 , while those of medicine and dentistry decreased by 64 to 899 , and only 2,698 students were working for a teacher's diploma compared with 2,900 in 1952-53. Of the full-time students, 63,560 were reading for a first degre $\Theta, 4,350$ for a first diploma, and 12,166 (including those working for a teacher's diploma) were engaged in research or other advanced work, the corresponding figures for 1952-53 being 64,753, 5,064 and 11,657, respectively.

The proportion of assisted students was slightly higher (71.9 per oent compared with 70.4 per cent in 1952-53), though still smaller than in 1951-52 (72.4 per cent) ; for England as a whole it increased from 72.9 to 74.2 per cent, and in Wales from 81.1 to 88.5 per cent, but in Scotland only from 55.7 to 56.8 per cent. Parliamentary grants, however, were 70.5 per cent of recurrent income and only 12 per cent comes from fees, $4 \cdot 3$ per cent from endowments, $3 \cdot 6$ per cent from local authority grants and $1 \cdot 6$ per cent from donations and subseriptions. For 1951-52 the corresponding figures were $14 \cdot 8,5 \cdot 2,4 \cdot 1$ and $1 \cdot 9$ per cent, respectively, with $66 \cdot 5$ per cent from Parliamentary grants. The ratio of staff to students continued to improve, the full-time teaching staff numbering 9,514 compared with 9,098 during 1952-53. The increase was chiefly in lecturers (285), but there were 37 additional professors, 69 more senior lecturers and 12 more readers, assistant professors and independent lecturers, with a further decrease of 120 in assistant lecturers and demonstrators to 1,162 .

Of the full-time students, 62,173 were in England, 4,431 in Wales and 13,998 in Scotland, the distribution in English universities and university colleges being 14,867 at Oxford and Cambridge, 18,125 at London, and 29,181 at others. Except at Bristol, Leeds, Reading, Southampton and Oxford, where there were slight increases, there were slight decreases in the number of students at English universities and university colleges, but only at Manchester (-159), Oxford $(+159)$ and North Staffordshire University College was the change more than one hundred and only for the last was it significant in relation to the total (495 for 1953-54). In Scotland thero were decreases at Abordeen (-95), Glasgow $(-156)$ and Edinburgh $(-56)$, and increases at Glasgow Koysl Technical College $(+76)$ and St. Andrews $(+9)$. The proportion of full-time students in Britain residing in colleges and halls of residence increased to $28 \cdot 1$ per cent ; of these 22,625 students, 8,069 were at Oxford and Cambridge, 11,565 at other 